\title{
PKM Kelas Online Panduan Pemeriksaan Ibu Hamil di Masa Pandemi Covid-19 Untuk Bidan Praktik Mandiri Tahun 2020
}

\author{
Ari Waluyo, Nani Aisyiyah, Yenni Ariestanti, Titik Widayati \\ Universitas Respati Indonesia \\ yariestanti@yahoo.com
}

\begin{abstract}
Abstrak
Tenaga kesehatan seperti dokter, perawat, bidan dan tenaga medis lainnya merupakan garda terdepan dalam menangani pasien Coronavirus Disease atau covid-19. Semua elemen dalam tenaga medis bekerja sesuai kemampuannya. Lonjakan pasien dengan kasus positif tiap hari kian bertambah, ini menjadi tantangan berat bagi tenaga medis ditambah lagi dengan penggunaan alat pelindung diri yang tidak sesuai standar.Pada masa pandemi Covid-19 banyak ibu hamil yang enggan memeriksakan kehamilannya di tempat pelayanan kesehatan karena takut tertular virus corona, dan adanya anjuran menunda pemeriksaan kehamilan dan kelas ibu hamil, serta adanya ketidak siapan layanan dari segi tenaga dan sarana prasarana termasuk Alat Pelindung Diri, padalal pemeriksaan kehamilan tetap diperlukan secara rutin guna mengetahui kondisi kesehatan ibu dan janin Bidan adalah profesi kesehatan yang paling familiar di tengahtengah masyarakat, pelayanan atas segala keluhan menyangkut kesehatan masyarakat terutama yang menyangkut kesehatan ibu dan anak mampu dijalankan bahkan dengan segala keterbatasan alat kesehatan dan obat-obatan, begitupun perannya di masa pandemi covid-19 ini Melakukan identifikasi masalah, bertujuan untuk mendapatkan data sejauhmana pemahaman bidan praktik mandiri mengenai panduan pemeriksaan ibu hamil di masa pandemi covid-19. Melakukan Penyuluhan, bertujuan untuk meningkatkan pengetahuan para bidan praktik mandiri mengenai :Panduan pemeriksaan ibu hamil di masa pandemi Covid-19 Upaya pencegahan dari Covid 19, Melakukan Evaluasi program yang telah dilakukan, bertujuan untuk melihat sejauhmana keberhasilan program yang telah dilakukan, dengan cara tanya jawab Kegiatan kelas online panduan pemeriksaan ibu hamil di masa pandemi Covid-19 melalui daring ini diperoleh hasil yaitu 126 peserta yang mengikuti kelas online mengunakan zoom dan youtube.. Narasumber pertama memberikan materi tentang panduan pemeriksaan ibu hamil di masa pandei Covid-19, narasumber ke 2 memberikan materi tentang inovasi dan kreativitas dalam mengelola bidan praktik mandiri di masa pandemi dan narasumber ke 3 memberikan sharing tentang menjalankan praktik bidan di masa pandemi Covid-19.Peserta berpartisipasi aktif dalam kegiatan ini.
\end{abstract}

Kata Kunci : Ibu Hamil, Kelas Online,Covid -19, BPM

\begin{abstract}
Health workers such as doctors, nurses, midwives and other medical personnel are at the forefront of dealing with Coronavirus Disease or Covid-19 patients. All elements in medical personnel work according to their abilities. The increase in patients with positive cases every day is increasing, this is a formidable challenge for medical personnel coupled with the use of personal protective equipment that is not up to standard. During the Covid-19 pandemic, many pregnant women were reluctant to have their pregnancy checked at health care facilities for fear of contracting the virus. Corona virus, and the recommendation to postpone pregnancy check-ups and classes for pregnant women, as well as the unpreparedness of services in terms of personnel and infrastructure including Personal Protective Equipment, although routine pregnancy checks are still needed to determine the health condition of the mother and fetus. Midwives are the most familiar health professions. In the midst of the community, services for

http://ejournal.urindo.ac.id/index.php/PAMAS
\end{abstract}


all complaints regarding public health, especially those concerning maternal and child health, are able to be carried out even with all the limitations of medical equipment and medicines, as well as its role in this COVID-19 pandemic. or the extent of understanding of independent practice midwives regarding guidelines for examination of pregnant women during the COVID19 pandemic. Conducting Counseling, aims to increase the knowledge of independent practice midwives regarding: Guidelines for examining pregnant women during the Covid-19 pandemic Prevention efforts from Covid 19 Conducting evaluations of programs that have been carried out, aiming to see the extent of the success of the programs that have been carried out, by way of questions and answers The online class activity that guides the examination of pregnant women during the Covid-19 pandemic through online results obtained, namely 126 participants who took online classes using zoom and youtube. provide material on innovation and creativity in managing independent practice midwives during the pandemic and the 3rd resource person provides sharing about running midwifery practices during the Covid-19 pandemic. Participants actively participate in this activity.

Keywords: Pregnant Women, Online Class, Covid -19, BPM

\section{PENDAHULUAN}

Tenaga kesehatan seperti dokter, perawat, bidan dan tenaga medis lainnya merupakan garda terdepan dalam menangani pasien Coronavirus Disease atau covid-19. Semua elemen dalam tenaga medis bekerja sesuai kemampuannya. Lonjakan pasien dengan kasus positif tiap hari kian bertambah, ini menjadi tantangan berat bagi tenaga medis ditambah lagi dengan penggunaan alat pelindung diri yang tidak sesuai standar, sehinnga banyak tenaga medis yang menjadi korban dan ikut tertular.

Ketua Umum Pengurus Pusat Ikatan Bidan Indonesia (PP IBI) dalam keterangannya di suara.com mengumumkan sudah ada ratusan bidan positif corona Covid 19 sebanyak 218, dengan dua diantaranya meninggal dunia, 744 orang bidan berstatus ODP dan 48 berstatus PDP, data ini baru menggambarkan $25 \%$ dari total bidan berpraktik mandiri di selurh Indonesia atau baru berasal dari 9.296 bidan.

Dan dalam perjalanannya saat pandemi ini berlangsung ada 974 bidan tutup dan tidak melakukan praktik mandiri dengan alasan APD yang kurang, ada yang masih menjalani isolasi sebagai ODP/PDP dan lain sebagainya.

Pada masa pandemi Covid-19 banyak ibu hamil yang enggan memeriksakan kehamilannya di tempat pelayanan kesehatan karena takut tertular virus corona, dan adanya anjuran menunda pemeriksaan kehamilan dan kelas ibu hamil, serta adanya ketidak siapan layanan dari segi tenaga dan sarana prasarana termasuk Alat Pelindung Diri, padalal pemeriksaan kehamilan tetap diperlukan secara rutin guna mengetahui kondisi kesehatan ibu dan janin. Dampak pandemi lainnya pada kesehatan ibu adalah terjadinya peningkatan angka kehamilan yang cukup tajam di berbagai daerah. Dengan adanya pandemi ini setiap pasangan yang sedang menantikan kelahiran bayinya harus menyesuaikan kondisi yang ada. Pemeriksaan kehamilan juga harus mengikuti protokol pencegahan covid-19. 
Bidan adalah profesi kesehatan yang paling familiar di tengah-tengah masyarakat, pelayanan atas segala keluhan menyangkut kesehatan masyarakat terutama yang menyangkut kesehatan ibu dan anak mampu dijalankan bahkan dengan segala keterbatasan alat kesehatan dan obat-obatan, begitupun perannya di masa pandemi covid-19 ini. Maka dengan itu diperlukannya acuan atau pedoman bagi bidan dalam memberikan pelayanan ANC, persalinan dan PNC di masa pandemi Covid-19

Maka dari itu permasalahan mitra yang didapatkan adalah sebagai berikut:

1. Tingginya angka kejadian bidan yang terkena Covid-19

2. Perlunya sosialisasi dari panduan pemeriksaan ibu hamil di masa Pandemi Covid-19

\section{METODE}

1. Melakukan identifikasi masalah, bertujuan untuk mendapatkan data sejauhmana pemahaman bidan praktik mandiri mengenai panduan pemeriksaan ibu hamil di masa pandemi covid-19.

2. Melakukan Penyuluhan, bertujuan untuk meningkatkan pengetahuan para bidan praktik mandiri mengenai :

a. Panduan pemeriksaan ibu hamil di masa pandemi Covid-19

b. Upaya pencegahan dari Covid 19, dll

3. Melakukan Evaluasi program yang telah dilakukan, bertujuan untuk melihat sejauhmana keberhasilan program yang telah dilakukan, dengan cara tanya jawab 


\section{Jurnal Pelayanan dan Pengabdian Masyarakat (PAMAS)}

\section{HASIL PENGABDIAN MASYARAKAT}

Mekanisme pelaksanaan pengabdian kepada masyarakat ini di awali dengan pengusulan topik, judul serta tehnik pelaksanaannya oleh ketua. Dosen yang mengusul pengabdian ini, akan terlibat langsung dalam rangkaian kegiatan mulai dari persiapan, pelaksanaan dan evaluasi. Pelaksanaan seminar online ini dilaksanakan oleh dosen-dosen di Prodi DIII Kebidanan Fakultas IImu Kesehatan Universitas Respati Indonesia.

Pelaksanaan kegiatan dilakukan dalam waktu 1 minggu dengan sebelumnya melakukan persiapan untuk melaksanakan kelas online, promosi/menyebarkan undangan melalui media online (group WA, facebook, instagram dII) dan kemudian pelaksanaan kelas online.

Kegiatan di awali dengan sambutan dari Kepala LPPM, kemudian dilanjutkan dengan pemberian materi menganai panduan pemeriksaan ibu hamil di masa Pandemi Covid-19, dan terakhir dilakukan evaluasi dengan cara melakukan tanya jawab.

Kegiatan kelas online panduan pemeriksaan ibu hamil di masa pandemi Covid-19 melalui daring ini diperoleh hasil yaitu ada kurang lebih 126 peserta yang mengikuti kelas online mengunakan zoom dan youtube. Panitia sendiri berjumlah 4 orang, 3 orang narasumer dan dibantu oleh 3 orang IT. Narasumber pertama memberikan materi tentang panduan pemeriksaan ibu hamil di masa pandei Covid-19, narasumber ke 2 memberikan materi tentang inovasi dan kreativitas dalam mengelola bidan praktik mandiri di masa pandemi dan narasumber ke 3 memberikan sharing tentang menjalankan praktik bidan di masa pandemi Covid-19.



Gambar 1. Pemateri 1. dr. Ari SPoG 


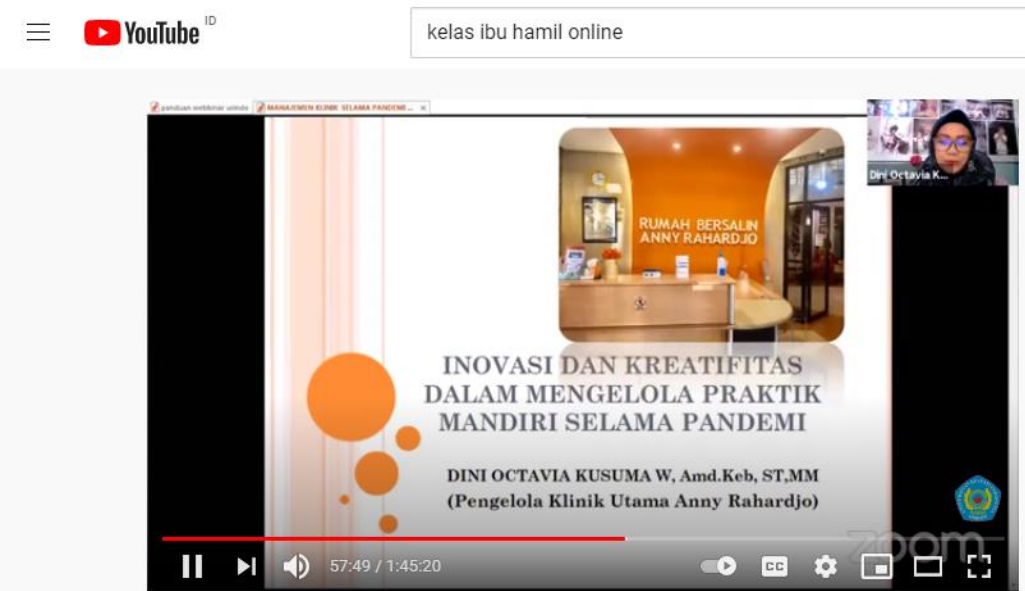

$†$ 器

Gambar 2. Pemateri 2 : dini Octavia W, Amd.Keb, ST,MM

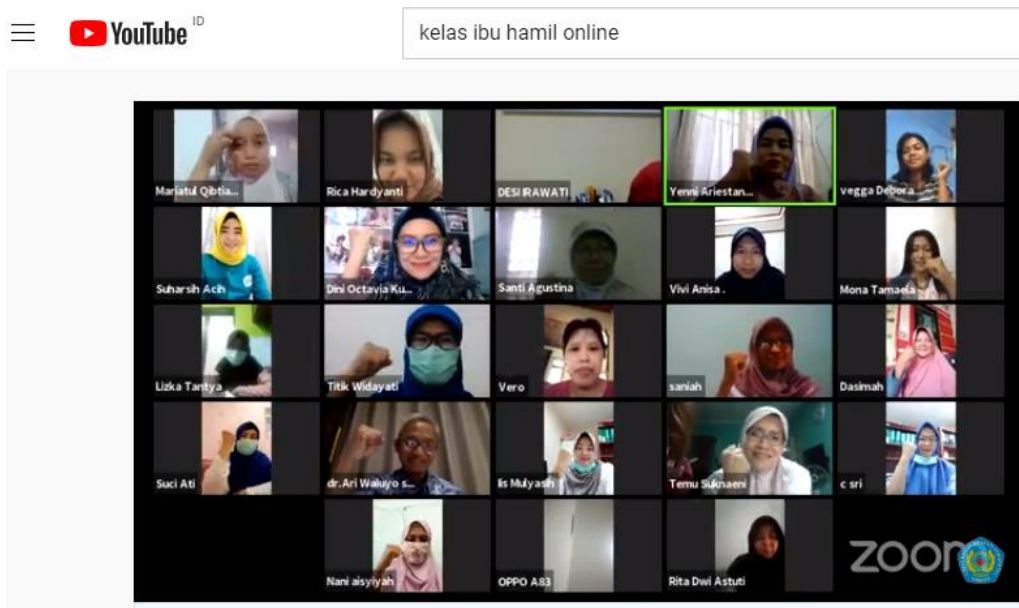

$\times \quad Q \quad$ e

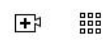

Gambar 3. Peserta Webinar Online

Peserta berpartisipasi aktif dalam kegiatan ini dibuktikan dengan antusiasme peserta dengan mengikuti acara ini sampai selesai, adapun hasil tanya jawabnya adalah sebagai berikut :

1. Pertanyaan : Apakah APD level ANC bisa digunakan untuk visite ke ruangan, dengan pasien terlebih dulu di screning sebelum ke ruangan?

Jawab : pasien di ruang rawat inap lebih sedikit paparan dengan covid, berbeda dengan pasien di poli, harusnya tidak diperbolehkan menggunakan APD level ANC visite ke ruangan, karena pasien bisa terpapar dari APD yang kita gunakan.

2. Pertanyaan : Bila pasien di screning covid IGg reaktif Igm nya non reaktif, pasien dengan gambaran paru bersih, pasien tidak dianjurkan untuk dilakukan PCR, kemudian riwayat di ruangan biasa, untuk perawatan pasien di ruangan berdasarkan panduan apa? 


\section{Jurnal Pelayanan dan Pengabdian Masyarakat (PAMAS)}

Jawab: tergantung dari sarana prasarana di RS, untuk pemeriksaan PCR membutuhkan Lab khusus, maka pemerintah memberikan jalan lain, paling baik panduan rawat berdasarkan hasil PCR, harusnya setiap RS mempunyai satgas, dan satgas inilah yang menentukan pasien dengan Covid.

3. Pertanyaan : Bagaimana memberikan informasi kepada klinik atau RS yang masih memberikan waktu kunjung kepada pasien rawat?

Jawab: Untuk pelayanan kepada pasien sebaiknya kita memberikan info bahwa pelayanan dapat menggunakan online, kemudian jadwal praktik ditambah lagi, sehingga tidak terjadi penumpukan, dan pengantar tidak diperbolehkan masuk. Pasien juga di berikan info tentang bahaya dari covid ini.

\section{KESIMPULAN}

Kelas Online Panduan pemeriksaan ibu hamil di masa Pandemi Covid-19 untuk Bidan Praktik Mandiri diperoleh hasil diantaranya adalah ada sekitar 126 peserta yang mengikuti kegiatan ini melalui apliaksi zoom dan youtube. Peserta berpartisipasi aktif dalam kegiatan ini dibuktikan dengan antusiasme peserta dengan mengikuti acara dari awal sampai akhir acara serta banyaknya pertanyaan yang muncul pada saat sesi tanya jawab. Dengan adanya kegiatan ini peserta menjadi bertambah pengetahuannya mengenai panduan pemeriksaan ibu hamil di masa pandemi Covid-19 serta pemasaran dari praktik Bidan Mandiri dan bisa diterapkan terutama pada masa pandemi ini.

\section{DAFTAR PUSTAKA}

1. Buku Kesehatan Ibu dan Anak (KIA) http : // kesga .kemkes. go.id /images/ pedoman /buku\% 20kia\%202019.pdf

2. Rekomendasi POGI penaganan Infeksi Virus Corona pada Maternal https://bit.ly/RekomendasiPOGIdan IDAI

3. Materi KIE tentang Dapatkan Pelayanan KB dan Kespro dengan Meminimalkan Tertular COVID-19. http://kesga.kemkes.go.id/ 